\title{
PENDAMPINGAN PEMANFAATAN MEDIA PEMBELAJARAN BERBASIS OPEN DAN FREEWARE DI SMA PANCASILA TAMBOLAKA SUMBA BARAT DAYA
}

\author{
Moh. Erkamim ${ }^{1}$, Sapto Priyadi², Vera Wati ${ }^{3}$ \\ ${ }^{1,2,3}$ Universitas Tunas Pembangunan Surakarta \\ *e-mail: erkamim@lecture.utp.ac.id
}

\begin{abstract}
Abstrak
Pengabdian masyarakat ini bertujuan untuk untuk menambah pengetahuan dan pemahaman guru dan siswa di SMK Pancasila Tambolaka Sumba Barat Daya serta beberapa sekolah menengah lainnya, mengenai penggunaan media online learning dalam proses pembelajaran selama pandemi Covid-19 yang mengharuskan pembelajaran dari rumah. Pengabdian masyarakat ini dilakukan di aula dan laboratorium komputer SMK Pancasila Tambolaka Sumba Barat Daya. Pengabdian ini berupa pelaksanaan pelatihan dan pendampingan pemanfaatan media online learning free google classroom dan gmeet. Pengabdian ini dihadiri oleh 28 peserta yang merupakan guru di SMK Negeri 1 Pancasila dan beberapa sekolah lainnya di Sumba Barat. Materi yang diberikan diantaranya Sosialisasi Pembelajaran, Penggunaan Google Classroom, Penggunaan Google Form, Penggunaan Google Meet, Semua Mapel dalam 1 Classroom dan Simulasi. Berdasarkan hasil evaluasi dari pelaksanaan pengabdian pada masyakat dengan pelatihan dan diskusi yang dilakukan selama 5 hari dapat diperoleh (1) media online learning free google classroom dan gmeet dapat digunakan oleh guru-guru, (2) alternatif solusi dalam menghadapi pembebelajaran yang mendadak online salam pandemi covid-19 (3) guruguru telah berhasil menggunakan fitur-fitur pada media online learning free google classroom, google form dan gmeet. Berdasarkan dari hasil evaluasi dapat disimpulkan bahwa pengabdian pada masyarakat ini telah berhasil dilakukan dengan baik.
\end{abstract}

Kata kunci: elearning, pandemi, online learning, pembelajaran

\section{Abstract}

This community service aims to increase the knowledge and understanding of teachers and students at SMK Pancasila Tambolaka, Southwest Sumba and several other high schools, regarding the use of online learning media in the learning process during the COVID-19 pandemic which requires learning from home. This community service is carried out in the hall and computer laboratory of SMK Pancasila Tambolaka, Southwest Sumba. This service is in the form of training and mentoring in the use of online learning media, free google classroom and gmeet. This service was attended by 28 participants who are teachers at SMK Negeri 1 Pancasila and several other schools in West Sumba. The materials provided include Learning Socialization, Use of Google Classroom, Use of Google Forms, Use of Google Meet, All Subjects in 1 Classroom and Simulation. Based on the evaluation results from the implementation of community service with training and discussions carried out for 5 days, it can be obtained (1) online learning media free google classroom and gmeet can be used by teachers, (2) alternative solutions in dealing with sudden online learning during a pandemic covid-19 (3) teachers have successfully used the features on the free online learning media google classroom, google form and gmeet. Based on the results of the evaluation, it can be concluded that this community service has been carried out well.

Keywords: elearning, pandemic, online learning, learning

\section{PENDAHULUAN}

Pandemi Virus Disease (Covid-19) yang melanda seluruh Negara di Dunia, telah memberikan tantangan tersendiri bagi lembaga pendidikan, khususnya pendidikan dasar sampai pendidikan tinggi. Guna mengantisipasi penularan virus tersebut pemerintah telah mengeluarkan berbagai kebijakan, seperti isolasi, social and physical distancing hingga pembatasan sosial berskala besar (PSBB). Kondisi ini mengharuskan warganya untuk tetap stay at home, bekerja, beribadah dan belajar di rumah. Kondisi demikian menuntut lembaga pendidikan untuk melakukan inovasi dalam proses pembelajaran. 
Pengabdian masyarakat ini bertujuan untuk untuk menambah pengetahuan dan pemahaman Guru dan Siswa di SMK Pancasila Tambolaka Sumba Barat Daya serta beberapa sekolah menengah lainnya, mengenai penggunaan media online learning dalam proses pembelajaran selama pandemi covid-19 yang mengharuskan pembelajaran dari rumah. Pengabdian masyarakat ini dilakukan di aula dan laboratorium komputer SMK Pancasila Tambolaka Sumba Barat Daya. Pengabdian ini berupa pelaksanaan pelatihan dan pendampingan pemanfaatan media online learning free google classroom dan gmeet. Pengabdian ini dihadiri oleh 28 peserta yang merupakan guru di SMK Negeri 1 Pancasila dan beberapa sekolah lainnya di sumba barat. Materi yang diberikan diantaranya Sosialisasi Pembelajaran, Penggunaan Google Classroom, Penggunaan Google Form, Penggunaan Google Meet, Semua Mapel dalam 1 Classroom dan Simulasi.

Akan tetapi, dalam pembelajaran daring ini tidak terlepas dari permasalahan yang menjadi hambatan dalam pelaksanaannya, termasuk pembelajaran daring kepada guru pada sekolah dasar sampai menengah atas. Oleh karenya, diperlukan berbagai jalan keluar alternatfi sebagai solusi dan juga langkah yang diambil di masa yang akan datang sebagai proyeksinya. Hambatan, solusi dan proyeksi pembelajaran daring pada guru penting untuk diketahui, mengingat sistem pembelajaran ini digunakan oleh mendistribusikan materi tugas maupun pelajar tatap muka (online).

Sebagai guru bukan hanya dituntut untuk ahli dalam menyampaikan materi/bahan ajar secara offline (tatap muka di kelas), tetapi dituntut juga dapat menggunakan sistem pembelajaran daring atau elearning. Banyak metode online yang dapat dimanfaatkan dengan beberapa alternatif seperti LMS Moodle, Google Classroom \& G-meet, Edmodo, Zoom dan lain-lain.

\section{METODE}

1. Kerangka Pemecahan Masalah

Kerangka pemecahan masalah dari pengabdian pada masyarakat ini disajikan pada alur dengan kerangka masalah pada gambar 1 .

\section{Kerangka Pemecahan Masalah}

1. Diterapkannya pembelajaran online secara mendadak selama Pandemi Covid-19

2. Minimnya pembekalan online learning di beberapa SMA/SMK di Sumba Barat dimana daerah ini merupakan daerah pemekaran / daerah baru.
1. Mahami kondisi masyarakat terutama guru dan murid selama diberlakukannya WFH di daerah Sumba Barat

2. Melakukan workshop pendampingan mengenai penggunaan media online learning dalam proses pembelajaran.

Gambar 1. Kerangka Pemecahan Masalah

Berdasarkan kerangka pemecahan masalah maka didapat kegiatan pengabdian alan dilaksanakan sesuai alu pada gambar 2 . 


\section{Kerangka Kegiatan Pengabdian kepada Masyarakat}

\begin{tabular}{|l|l}
$\begin{array}{l}\text { Observasi kondisi masyarakat (guru } \\
\text { dan siswa) yang menjadi kendala } \\
\text { selama pembelajaran daring/online }\end{array}$ & $\rightarrow \begin{array}{l}\text { Mempelajarai informasi permasalahan } \\
\text { dari masyarakat dengan solusi tema } \\
\text { pengabdian yang akan diberikan }\end{array}$ \\
\hline
\end{tabular}

\begin{tabular}{|c|c|c|c|}
\hline $\begin{array}{l}\text { Laporan dan } \\
\text { Evaluasi }\end{array}$ & $\begin{array}{l}\text { Pelaksanaan } \\
\text { Kegiatan } \\
\text { Pengabdian }\end{array}$ & $\begin{array}{l}\text { Pengajuan } \\
\text { Proposal } \\
\text { Kegiatan }\end{array}$ & $\begin{array}{l}\text { Menyusun rancangan kegiatan } \\
\text { dan materi untuk membantu } \\
\text { permasalahan (guru dan siswa) }\end{array}$ \\
\hline
\end{tabular}

Gambar 2. Kerangka Kegiatan Pengabdian kepada Masyarakat

\section{Metode Pengabdian}

Metode kegiatan yang dilakukan dalam pengabdian kepada masyarakat ini adalah dalam bentuk sosialisasi sampai pelatihan menggunakan online learning berbasis free dengan platform google classroom dengan membagi kebeberapa materi pokok, adapun materi pokoknya sebagai seperti pada gambar 3 .

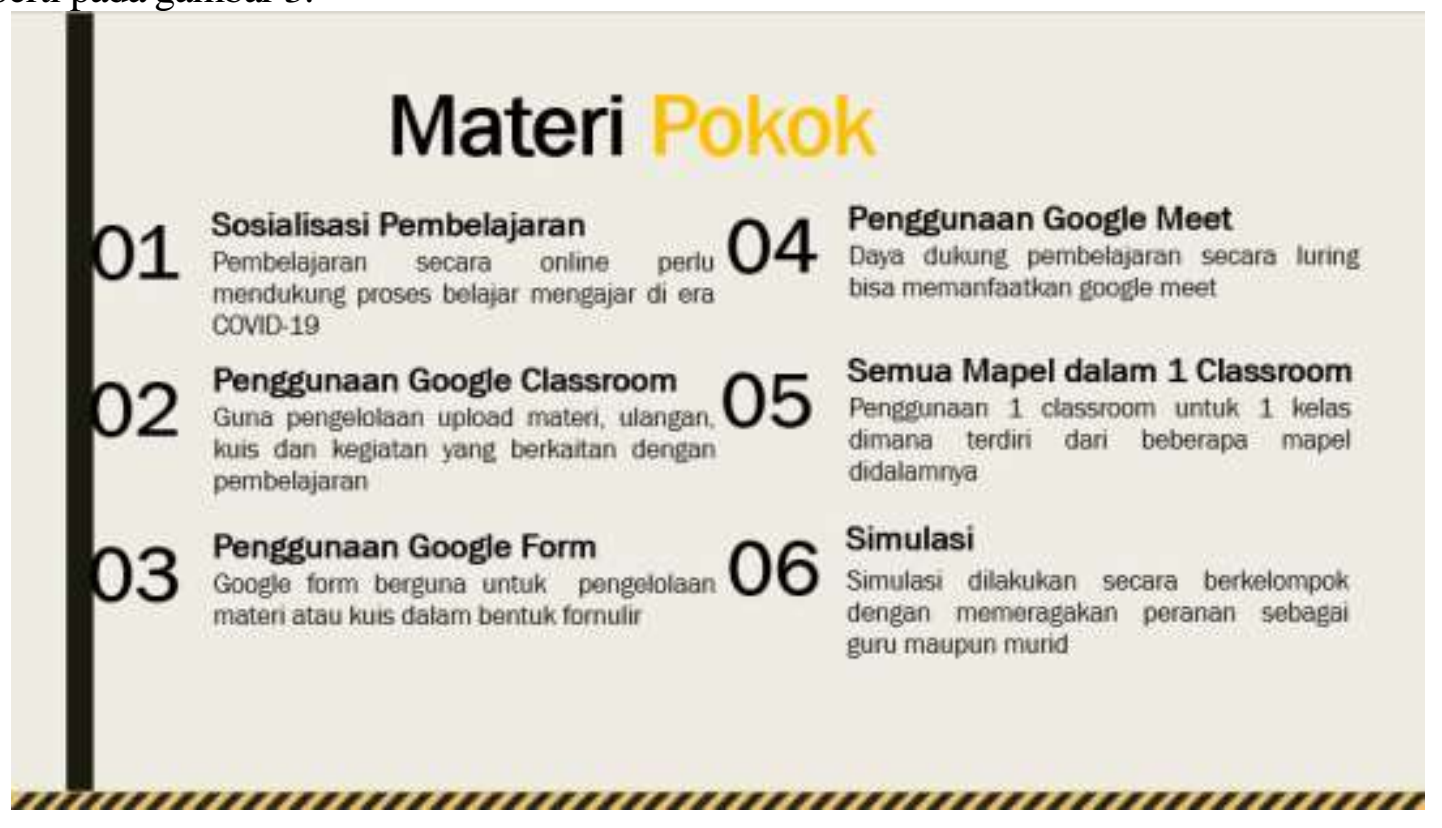

Gambar 3. Materi Pokok

Untuk memberikan kesempatan bagi guru yang lain dalam implementasi media learning online google classroom dan meeting, maka akan dilakukan juga pendampingan secara online group bagi yang membutuhkan bantuan dalam pengoperasian media learning online google classroom dan meeting. Pelatihan dilakukan selama 3 hari dimana hari pertama lebih fokus dalam memberikan informasi media learning online google classroom dan meeting, mengakses dan mengelola kelas, serta pengisian konten. Kemudian akan dilakukan pendampingan secara online, dimana guru-guru dapat berkomunikasi dengan tim secara online jika masih ada kendala dalam penggunaan media learning online google classroom dan meeting. 


\section{HASIL DAN PEMBAHASAN}

Kabupaten Sumba Barat Daya adalah salah satu Kabupaten dari 4 (empat) Kabupaten yang ada di Pulau Sumba dan 22 Kabupaten/ Kota di Provinsi Nusa Tenggara Timur (NTT) yang dibentuk berdasarkan Undang-undang Nomor 16 Tahun 2007 tentang Pembentukan Kabupaten Sumba Barat Daya dalam Wilayah Provinsi Nusa Tenggara Timur (Lembaran Negara Republik Indonesia Tahun 2007 Nomor 18, Tambahan Lembaran Negara Republik Indonesia Nomor 4692) dengan batas-batas wilayah administratif sebagai berikut:

$\begin{array}{ll}\text { Sebelah Utara } & \text { : Selat Sumba } \\ \text { Sebelah Selatan } & \text { : Samudera Indonesia } \\ \text { Sebelah Timur } & \text { : Kabupaten Sumba Barat } \\ \text { Sebelah Barat } & \text { : Samudera Indonesia }\end{array}$

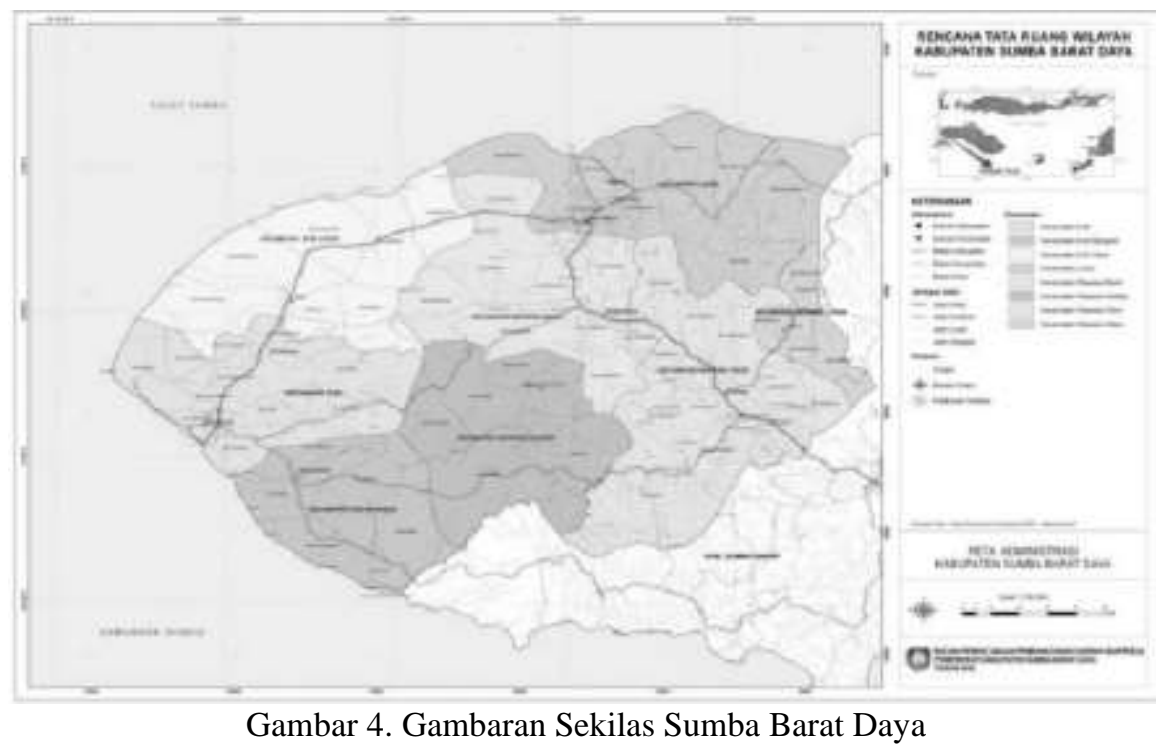

Kegiatan Pengabdian Masyarakat tahun 2021 Sosialisasi Media Pembelajaran Berbasis Open dan Freeware dimasa Pandemi Covid-19 bagi guru dan siswa SMK Pancasila Tambolaka Sumba Barat Daya dan beberapa SMA/SMK terdekat, dilaksanakan pada tanggal 22-26 Februari 2021. Dari target 30 guru yang diharapkan untuk hadir, terdapat 28 guru dan 80 siswa yang hadir ditambah Kepala Sekolah SMK Pancasila Tambolaka Sumba Barat Daya yang menyambut sekaligus mendampingi kegiatan ini seperti pada gambar 4 .

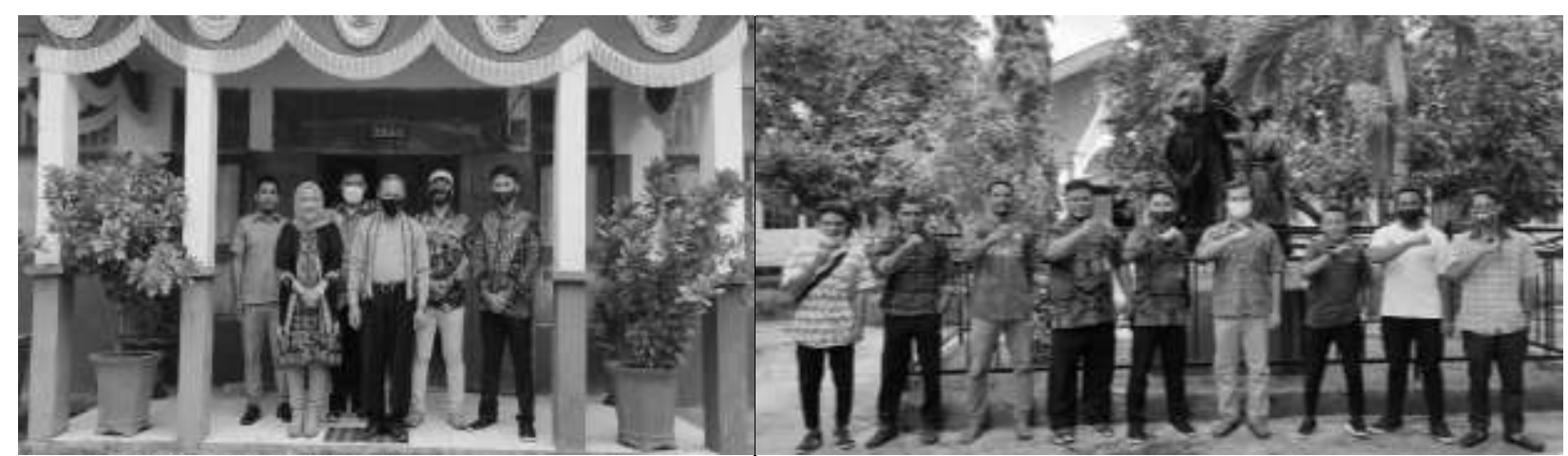

Gambar 5. Sambutan Pimpinan dan Guru Sekolah 
Pelaksanaan pelatihan dan pendampingan pemanfaatan media online learning di SMK Pancasila Tambolaka Sumba Barat Daya diakhiri oleh evaluasi pelaksanaan dan diskusi pelaksanaan Pengabdian pada Masyarakat tahun depan. Kegiatan ini diikuti oleh Tim Pelaksana Pengabdian beserta Kelapa Sekolah, Wakil Kepala bidang Kurikulum beserta Wakil Kepala bidang Kesiswaan.
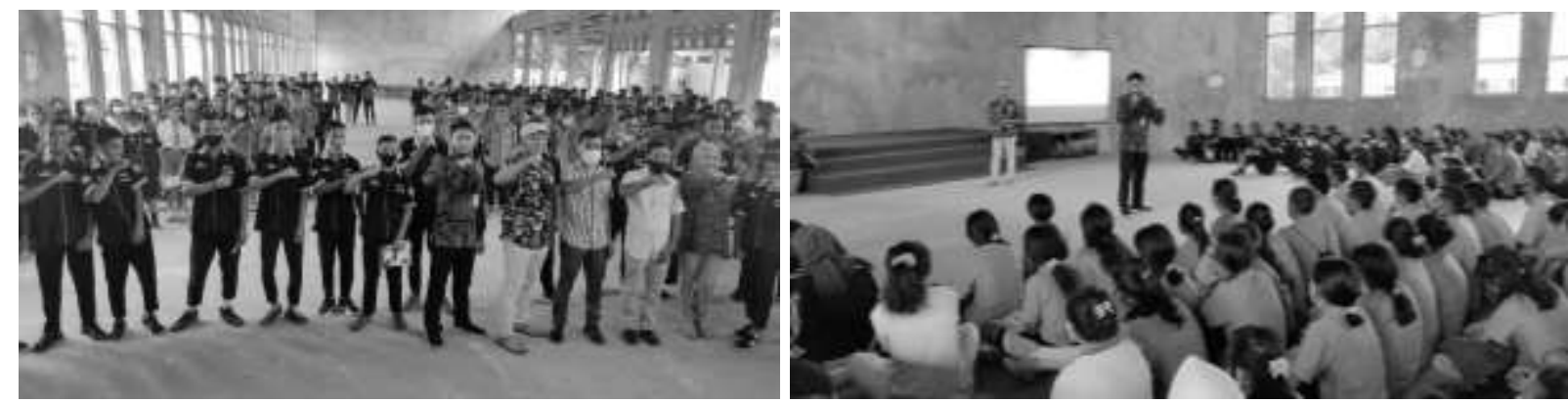

Gambar 6. Sosialisasi dan Diskusi Pembelajaran Online dalam masa Pandemi

\section{KESIMPULAN}

Media online learning free google classroom dan gmeet berhasil diimplementasikan guru maupun siswa dilinkungan SMK Pancasila Tambolaka Sumba Barat Daya dan beberapa sekolah lain yang mengikuti. Pelatihan dan pendampingan berhasil dilakukan sesuai rencana. Hasil penerapan pembelajaran di rumah selama pandemi bisa tersolusikan dengan menggunakan kelas online atau virtual class dengan penyampaian pelajaran secara lansung, pendampingan pengoperasian media online learning free google classroom dan gmeet dapat memberikan kontribusi positif terhadap peningkatan pemanfaatan teknologi untuk proses pembelajaran.

Saran untuk kedepan supaya dapat dikembangkan lagi elearning mandiri di sumba barat yang dapat dikelola oleh pemerintah daerah (Disdik) dengan menyediakan server khusus dalam memfasilitasi pembelajaran online.

\section{UCAPAN TERIMA KASIH}

Terima kasih kepada seluruh jajaran Pemerintah Sumba Barat Daya, Kepala sekolah di wilayah Tamboloka khsusnya SMK Pancasila yang telah memberikan tempat untuk malaksanakan pengabdian dan tidak lupa Tim pengabdian masyarakat Universitas Tunas Pembangunan Surakarta mengucapkan banyak terima kasih kepada Direktorat Riset dan Pengabdian Masyarakat (DRPM) Universitas Tunas Pembangunan atas pendanaannya untuk pelaksanaan pengabdian masyarakat tahun 2021 dengan lancar.

\section{DAFTAR PUSTAKA}

Darmawiguna I G. M., Pradnyana I M. A., Pradnyana G. A., Suwin I N. P., 2017, Pelatihan, Pendampingan, Dan Evaluasi Pemanfaatan Elearning Berbasis Moodle Di Smk Negeri 1 Nusa Penida, Seminar Nasional Pengabdian Kepada Masyarakat ISBN : 978-602-6428-12-7

Hakim, A.B., 2016. Efektifitas Penggunaan E-Learning Moodle, Google Classroom Dan Edmodo. I-STATEMENT: Information System and Technology Management (eJournal), 2(1)

Tahta H.A., Nur A., Dwi F., Yenny M., Rian C.P., 2020. Pengenalan E-Learning Sebagai Media Pembelajaran Tatap Muka Secara Virtual Di Pondok Pesantren Darul Huffaz, Jurnal Pengabdian Kepada Masyarakat Ungu ( ABDI KE UNGU), Vol. 2 Issue 2. 